\title{
TEMPO'S PERSPECTIVE ON THE REPRESENTATION OF GOVERNMENT IN DEALING WITH COVID-19 CASES
}

\author{
Siti Setia Mintarsih ${ }^{1}$, Denny Kodrat ${ }^{2}$, and Raynessa Noor Emiliasari ${ }^{3}$ \\ STBA Sebelas April ${ }^{1}$, Sumedang, sitisetiamintarsih@gmail.com \\ STBA Sebelas April ${ }^{2}$, Sumedang, denny@stbasebelasaprilsumedang.ac.id \\ Universitas Majalengka ${ }^{3}$, Majalengka, raynesanoor@unma.ac.id
}

\begin{abstract}
Tempo.co as well-known mass media in Indonesia gains tremendous attention from public reader concerning Covid-19 pandemic. The influential news that it produced has discursive dimension that can be analyzed by Critical Discourse Analysis (CDA). Accordingly, this study is a textual analysis that uses CDA theory with purposive sampling from tempo.co news concerning Covid-19 pandemic posted in the early emergence of covid-19 in Indonesia. The collected data are five trending news from tempo.co posted from April to March. In this study, it can be found that Tempo.co portray this media as a 'watchdog' that serves to supervise those who have a power within politics (government). Tempo's newspaper produces text news that reflects to the government depiction in their policies. Thus, Tempo's newspaper led the readers to give a positive image to Tempo.co as an active and existent media in serving the truth. Tempo.co try to gain the public trust to consume their news, then Tempo will get a high profit in it.
\end{abstract}

Keywords: CDA; Ideology; Socio-culture; Mass Media

\section{INTRODUCTION}

In the midst of the Covid-19 pandemic issue that apprehension the public, media played an important role in providing information about Covid-19. Media are one of information sources that have a purpose to share a news (Westerman, 2015). Therefore, media are needed by the public. Media have a positive impact for public to create, disseminating, and exchanging information in news release (Lee, Hutton, Shu, 2015).

The media use covers both sides, not mixing facts and judgmental opinions, not broadcasting news based on prejudice. If there is misleading information, the media rectify it immediately because basically the media are the instrument in enlightening and improving the citizens' critical thinking. In this case, the mass media have a big role in building public opinion.

Beside the positive role, media also have a negative impact. The news that is spread by the media raises a lot of problem. The public easily consumes information they received from the media. Then, media is also supported and owned by capital owners. In media, the news represents those who exercise political and economic power. Newspapers, magazines and broadcast are not independent actors, although they have the potential to serve independent power. The news content shows the interests of the people who finance the media (Altschull, 1985).

The media play an important role as a connector between the government, health workers, and the public by reporting the latest news and important 
information. The principle of equality in cooperation is needed between the media and the government because the two parties need each other. The government needs media to socialize their programs to the public and the media itself needs the government as a source of news (Silalahi, 2010).

The phenomenon of media coverage the government's representation in Covid-19 cases is an important issue to investigate. All that was conveyed by President Joko Widodo, the difficulties are not the virus itself, but the anxiety, panic, and hoax news. Therefore, the media should not participate in causing excessive conflict in the Covid-19 cases. Tempo is known as one of the top and independent mass media in Indonesia which is not part of political party.

Tempo's perspective on government's representation in dealing with covid19 cases can be observed in a Tempo's newspaper on March 24, 2020 edition as "The government finally released the figures for people infected and suspected of being infected with Covid-19. Transparency is needed, not centralization". From the headlines of the Tempo's newspaper, the data contains a material process "released". "Government" in "finally released" is an actor which is conveyed by Tempo in its newspapers explicitly. The actor is not hidden in the clause. It means that Tempo tends to show government's representation in dealing with covid-19 cases if the actor is clearly mentioned. Tempo gives information in various fields quickly, including the latest information about Coronavirus Disease 2019 (COVID19) which is currently pandemic throughout the world.

In this research, the news does not contains only the information of Coronavirus Disease 2019 (COVID-19) but it shows the government's representation in dealing with it. Media frames public opinion through its information. It carefully serves the information to public because the impact of framing opinion is huge. That is why in the context of the mass media as an information institution, Karl Deutsch in Sobur (2009: 31) called it as the nerve of government. Media influences the readers' opinion of what the fact is because of its information. Therefore, language is an important element that can be observed for knowing hidden ideologies from the media. This is a central issue in the analysis of critical discourse. According to Eriyanto (2011: 6-7) the critical view assumes that the discourse of seeing language is always involved in power relations, especially in the formation of subjects, and various acts of representation contained in society. Statements which are obviously represented by language can be analyzed in this research as systemic functional linguistics in analyzing the texts through transitivity system.

Many researchers who discuss Critical Discourse Analysis are, for example, Putra and Triyono (2018), Bulan (2018), Purwanto (2017), Suharyo (2015), Zaini (2015). A whole purposes of these studies are to find out how the analysis of texts, social cognition, social context, representation of public figure and their power on media, also the ideology behind the news on media. From these previous studies, no studies have been found that examine the study of critical discourse analysis in mass media that analyzed the choices and intensity to represent the government in dealing covid-19 cases using Transitivity and Functional Grammar theory. Thus, this research exists to complete these deficiencies.

Based on the formers research, it can be concluded that the former research used different title and different research analysis. The researcher will analyze one of mass media, namely Tempo. The researcher choosing Tempo as the data source is because Tempo is known as the independent media which its chief does not 
involved in politics. This research contains two major points, namely: 1. Tempo depicts the government in covid-19 discourse. 2. The ideology behind the Covid19 discourse.

From the explanation above the researchers decide to create research entitled "Tempo's Perspective on The Representation of Government in Dealing with Covid-19 Cases". This research is expected to expand language analysis through critical discourse analysis and it is also hoped to be able to help the other researchers in executing the research based on interrelated theory as this research that employs both critical discourse analysis and systemic functional linguistics.

This research attempts to analyze the news of government's representation in dealing with Covid-19 cases in Tempo's online newspaper. The data analysis was performed by analyzing the news used Critical Discourse Analysis based on Fairclough theory.

\section{LITERATURE REVIEW}

The following section informs on the three-dimensional nature of critical discourse analysis as perceived by Fairclough (1992). Main components of this modal include text, discourse practice and socio-cultural practices, as illustrated in figure 1:

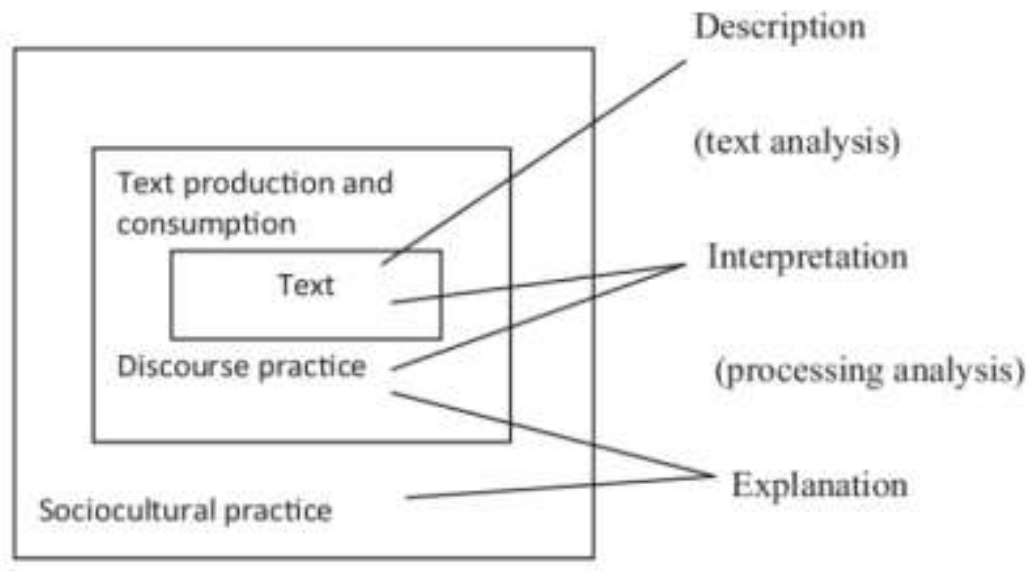

(social analysis)

Figure 1. Fairclough's three-dimensional framework

This research engages Fairclough's three-dimensional model of CDA. The dimensions constitute; text (spoken or written), discursive practice (production and consumption of text), and sociocultural practice. Fairclough's three-dimensional model in figure 1 is elaborated in the followings:

1. Text

The first level of the discourse model is text which includes all forms of communication (written, Spoken, visual). Analysis of a text can be made in different perspectives. A linguistic analysis should be sensitive to the representation, categories of participants, construction of their identities and their relation with one another and also with other institutions and groups. Both presence and absence of such elements are significant to give insight into the issues. Four aspects for linguistic analysis of a text: vocabulary, grammar, cohesion and text structure (Fairclough, 1992). These aspects draw heavily upon Halliday's (1985) systemic grammar as well as using concepts from other theories. The grammar 
provides different 'process types' and associated 'participants' as options, and systemic selection of a particular type may be ideologically significant (Fairclough, 1992). He considers it potentially powerful because this analytical dimension with a focus on systemic grammar not only analyses what is in the text but also what is absent.

\section{Vocabulary}

At lexical level, the analysis looks into certain lexical choices reflecting the attitude of writer, for example, the use of freedom fighter vs. terrorist. One way of analyzing vocabulary is to focus on the alternative wordings and their political and ideological significance. The analysis can also draw upon the ideological and political importance of particular metaphors and conflicts between alternative metaphors (Fairclough, 1992). While comparing two news reports by two different newspapers on the execution of Saddam Hussein, Asghar (2014) observes that a British newspaper The Sun referred to him as Saddam Hussein stood shaking in the dock, but was reported to have walked to his customary seat in the Pakistani newspaper, the Nation. In the same news reports, the lexical choices of non-human participants indicated the level of sympathy of both newspapers with Saddam Hussein, and hence reflect their ideological ties. In the following quote, the way the verbal process "shout" was used by both newspapers is noteworthy where the Sun referred to Saddam Hussein as '...the one-time leader of the country tried to shout him (the judge) down with cries...' and the Nation mentioned Saddam Hussein as continued to shout, denouncing the court'. Asghar highlights that the process shout was used in the Sun in a negative context whereas in the Nation the same process is more likely to communicate a positive implication while depicting Saddam indulged in a spirited activity even when he was arrested.

\section{Grammar}

This level includes transitivity relations, for example material, mental, relational, behavioural, verbal and existential processes, the role of participants in certain circumstances, passivization, nominalization etc. Grammatical analysis also includes clause grammar which looks at interpersonal meanings by focusing on the way social relations and social identities are marked in clauses (Fairclough 1992 ; Barker \& Galasinki 2001). Asghar and Al-Bargi (2014) analysed a short story to highlight how a critical discourse analysis of the story reveals the hidden ideologies.

\section{Text Structure}

Texts can be categorized in genres, where some texts may have defined principles of structuring the text such as news stories which usually follow the pattern called inverted pyramid (Fairclough 1995). Various genres can be analyzed in various ways such as narrative genres can trace out the correlation between the uses of tenses; texts related to descriptions may have discourse structuring patterns and use of tense and modality. While looking at the structure of a text in educational context, Asghar (2014) analyzes the text in tabular form to illustrate how a structural analysis of a text not only facilitates to understand the construction and development of thought but also guide readers on how to write texts in a logical sequence. Such an approach to examine the text critically tends to be analytical by nature, and also scientific, with a focus on linguistic construction and patterns used by the text producer. This approach to CDA involves micro analysis of the text. 
However, Fairclough (1992) believes that critical linguists tend to place too much emphasis upon the text as product than as process "which places a one-sided emphasis upon the effects of discourse in the social reproduction of existing social relations and structures. Fairclough believes that micro level analysis potentially can expose the hidden ideologies in a text. However, a simultaneous macro analysis is inevitable in order to gain information on the order of discourse as well as writers' intentions behind specific syntactical, lexical and semiotic preferences. A list of questions to be asked while analyzing a text following his proposed modal. He emphasized that the analysis should seek information about certain features of texts such as: social events the text is a part of, generic references of texts, inclusion or exclusion of other texts, internationality and interaction of texts, semantic relations, representation of human and nonhuman participants (Fairclough, 2003).

\section{Discursive practice}

The second level of discourse practice in Fairclough's model is important because it links text and sociocultural practice. Discourse practice involves receiving and producing messages. Discursive practice is constitutive in both conventional and creative ways: it contributes to reproducing social society (social identity, social relationships, systems of knowledge and belief) as it is, yet also contributes to transforming society (Fairclough, 1992). Discourse practice signifies the context which "ultimately means the very shape, meaning, and effect of the social world - the various social roles people play, the socially and culturally situated identities they take on, the social and cultural activities they engage in, as well as the material, cognitive, social, cultural, and political effects of these" (Gee, 2005). It is at this level where ideologies and sociocultural patterns are shaped and also shape the sociocultural practices. Discourse types and genres are also produced at this level. Thus the contextual analysis involves "the situational context (questions about time and place) and the intertextual context (looking for additional texts/information about or from producers and their product) as central for the process of interpretation" (Janks, 1997). The analysis of discursive practice should involve the analysis of text at micro as well as macro level (Fairclough, 1992). Micro analysis involves a precise focus on how the text is produced, who are the participants, what are the circumstances and what linguistic devices have been used. In other words, micro analysis mainly focuses on linguistic analysis, using some sort of framing for interpretation. Macro analysis looks at the nature of members' resources that is being drawn upon in order to produce and interpret texts, and to inquire whether it is being drawn upon in normative or creative way. Both of these analyses are interrelated and complement each other to give a more vivid and reliable interpretation.

\section{Sociocultural Practice}

The third level of Fairclough's discourse modal is sociocultural practice which maintains that discourse has potential to influence social structures and can play an active role in bringing change. It has various dimensions - economic, political, cultural, ideological - and discourse may be implicated in all of these without any of them being reducible to discourse (Fairclough, 1992). The dominant approach to understand and solve old as well as new and emerging problems, faced by many countries, especially the third world countries, has generally focused on systems, resources social action, social practices and forces of structure (Waller, 2006). He claims that the recent scholarship in the global sphere has suggested that 
issues of language and discourse might be one of the many other reasons of such problems. The advent of various versions of English on the globe as well as the concept of linguistic imperialism also supports this notion. In this sense, critical discourse analysis has potential in the social domain for critical research for the emancipation of the suppressed classes of a society. Discourse has taken a major role in socio-cultural reproduction and change in modern and late modern society (Fairclough, 1992). The action of uncovering the hidden ideologies as well as the practices behind the texts logically leads to challenging the status quo for a better change. This includes a critical and inclusive review of previous theory related to the relevant topic; a critical and inclusive review of previous empirical research related to the relevant topic; and, critical analysis of the distinction between authors' interpretation of their data and the actual empirical evidence presented. Use APA citation style 7th edition. The use of Mendeley is recommended to help you cite more consistently.

Regarding mass media as text in CDA perspective, there is no neutral media because of its various ideology. Media and politics are closely related as media propagates the thought and ideologies of elite (Van Dijk,1993). He describes media discourse as an advocate of elite's policy, hegemony and exploitation. It always favors the ideologies of the dominating class and state. Language used by them unfolds the discriminatory attitude of high towards the low. The mass media is often referred to as the fourth estate (fourth power) in socio-economic and political life. This is caused by a perception about the message that can play in relation to the development of the socio-economic and political life of the community (Sobur, 2009). Through the media, various parties are good individually, collectively and government agencies can build perceptions of public. Aside from being a tool to convey news, assessment, or general description of many things, the mass media can also play a role as an institution that can form public opinion, even become a pressure group on an idea that must be accepted by other parties (Sobur, 2009). In various analyzes about life social, economic, and political, media are often placed as one variable determinant. Even the media, especially in its position as an information institution, can be also seen as the most determining factor in the processes of change social-cultural and political. In the context of the mass media as an information institution, Karl Deutsch, called it "the artery of the government or the nerves of government" (Sobur, 2009). The mass media is considered nothing more than a tool communication "which is neutral and empty in itself. It only contains when filled in messages by the communicator to certain parties. It seems that by some people again, the mass media never and will not give more truth or "what reality existence ". He promises more dreams and fiction (Sobur, 2009: 33).

\section{METHOD}

News in Tempo's online newspaper from March until April 2020 was taken as the research object. The title and the content of the news that contain the government representation in dealing with Covid-19, government's regulation through Covid-19 and the data collection of Covid-19 that is explained by the government was analyzed in this research. Tempo is one of media in Indonesia which also reported Covid-19 cases, including representing the government dealing with it. Even, Tempo reported the news in its headlines. This media seem to 
attempts to tight an idealism value in running their business, as free mass media and by not standing in one group' interest. This is the reason for taking Tempo as the source of data in this study.

Five news were analyzed in this research. The news was selected from March until April based on the trending topic popping up in Google news application. The first topic in Tempo's online newspaper on March 13th, 2020 edition reported the problem of government's preparation in dealing with Covid19, in this research labeled as A1L1. The government's method of calculating the death ratio due to Covid-19 was the second data on April 24th, 2020 edition labeled as A2L2. Tempo's online newspaper on April 28th, 2020 edition reported the government's social assistance for Covid19-affected community misdirected, labeled as A3L3. The code of A4L4 on April 29th, 2020 edition was the report of community demands for government to fulfill their needs because of the implementation of the government's policies in dealing with Covid-19. The last data on March 24th, 2020 edition was about Agus Terawan Putranto dealing with Covid-19 cases as The Health Minister, labeled as A5L5. The object of the research is presented in the following table:

Table 1. Description of the Purposive Sampling Data Taken from Tempo.co

\begin{tabular}{|c|c|c|c|c|}
\hline $\begin{array}{l}\text { Number } \\
\text { of Data }\end{array}$ & Title of The News & Edition & Link of The News & Code \\
\hline 1. & $\begin{array}{c}\text { Dokter dan Ahli } \\
\text { Kesehatan Desak } \\
\text { Pemerintah Serius } \\
\text { Tangani Corona }\end{array}$ & $\begin{array}{c}\text { March } \\
13^{\text {th }}, 2020\end{array}$ & $\begin{array}{l}\text { https://koran.tempo.c } \\
\text { o/read/laporan- } \\
\text { utama/450960/dokter } \\
\text {-dan-ahli-kesehatan- } \\
\text { desak-pemerintah- } \\
\text { serius-tangani- } \\
\text { corona? }\end{array}$ & A1L1 \\
\hline 2. & $\begin{array}{c}\text { Pemerintah } \\
\text { Berkilah Soal Rasio } \\
\text { Kematian }\end{array}$ & $\begin{array}{c}\text { April } \\
24^{\text {th }}, 2020\end{array}$ & $\begin{array}{l}\frac{\text { https://koran.tempo.co }}{/ \mathrm{read} / \text { laporan- }} \\
\frac{\text { utama/452142/pemeri }}{\frac{\text { ntah-berkilah-soal- }}{\text { rasio-kematian }}}\end{array}$ & A2L2 \\
\hline 3. & $\begin{array}{c}\text { Salah Sasaran } \\
\text { Setelah Dikucurkan }\end{array}$ & $\begin{array}{c}\text { April } \\
28^{\text {th }}, 2020\end{array}$ & $\begin{array}{c}\frac{\text { https://koran.tempo.co }}{\text { /read/laporan- }} \\
\frac{\text { utama/452231/salah- }}{\text { sasaran-setelah- }} \\
\text { dikucurkan }\end{array}$ & A3L3 \\
\hline 4. & $\begin{array}{c}\text { Pemerintah Wajib } \\
\text { Penuhi Kebutuhan } \\
\text { Masyarakat }\end{array}$ & $\begin{array}{c}\text { April } \\
29^{\text {th }}, 2020\end{array}$ & 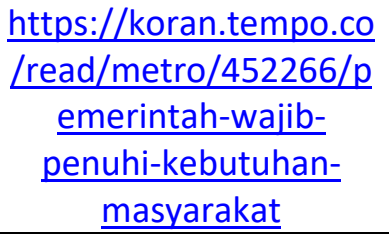 & A4L4 \\
\hline 5. & $\begin{array}{l}\text { Mundrulah } \\
\text { Terawan }\end{array}$ & $\begin{array}{c}\text { Maret } \\
24^{\text {th }}, 2020\end{array}$ & $\begin{array}{l}\text { https://koran.tempo.co } \\
\text { read/editorial/451250 } \\
\text { Lmundurlah-terawan? }\end{array}$ & A5L5 \\
\hline
\end{tabular}


The codes listed in the table 1 above were used for labeling the news. A1L1 means first data of first line. A2L2 means second data of second line. The third data of third line labeled A3L3. A4L4 means fourth data of fourth line. A5L5 means fifth data of fifth line.

\section{FINDINGS AND DISCUSSIONS}

In the dimension of discursive analysis, editorial procedures involved in the production of media texts (Fairclough, 1995). The relation between the content of media, especially the news is related to the media crew (journalists, editors and chief editor). In this dimension, the interpretation conducted on the processing of discourse which includes aspect of production, distribution and using of text. This section analyzes how media workers produce text.

Tempo's chief commissioner is Goenawan Mohamad. He has no relation with the government staff. Tempo is the first institution that has no affiliation with the government. In line with PT Tempo Inti Media, the vision of Tempo.co is a site to become a media in a reference effort to increase public freedom to think and give an argument. While the mission of Tempo.co is to produce a media product that is free from all pressures by accommodating and distributing a fair share of different voices. The realization of the text produced by Tempo, especially in the news of the government representation in dealing with Covid-19 was considered to be in line with the mission of Tempo, to produce multimedia products that are free from all pressures by accommodating and distributing a fair share of different sounds.

Tempo online newspaper is one of the online media in Indonesia which aims to provide services to readers of Tempo's daily in places that are difficult to reach by the Tempo distribution network. With the presence of Tempo online newspaper, the readers, especially in eastern Indonesia and abroad, can enjoy news of the day, no need to wait for the usual days. Tempo's newspaper is a development of the Majalah Berita Mingguan Tempo published by PT. Tempo Inti Media. Tempo's newspaper is not much different from others newspapers in Indonesia. Tempo delivered the actual news, issues around the economic, political, social and cultural. The difference site in the writing style, experience, editorial that made Tempo often take a different perspective from other newspapers. Such a principles come from Tempo Magazine, which has been published since March 1987 and as a derivative of Tempo's newspaper also has a style that is almost same in every news.

Tempo is the first institution which apply the concept of multimedia in Indonesia. Beginning with the presence of Tempo interactive (1996) through www.tempo.co.id site as a pioneer of news site in Indonesia, in 2008 appeared with a new comer with the site www.tempointeraktif.com. At present, the name of the site has been changed to www.tempo.co. To reach more the readers, Tempo's newspaper comes in the online or digital form, not only through the computer, but also presence Tempo for android, iPhone, iPad and freedom of web access that make it easy for readers to access information. All these conveniences can be assessed through www.tempo.co as a digital form.

The existence of Tempo's magazine, Tempo's newspaper, and Tempo's interactive, Tempo management then established the Tempo News Room (TNR) in 2001, a news agency that has a function as a news center for Tempo production media. Tempo News Room (TNR) is the center of news production for all the Tempo's news (in the form of web, newspaper and magazine) that also marks the 
era of convergence carried out by PT. Tempo Inti Media. TNR help to make the newspaper accordance with its media logic, not affiliated.

Here are some headlines that prove that Tempo.co reporting the news in accordance with the existing facts. Tempo prove that this media have no affiliated with the government. Thus, the news was presented without any pressure from the government.

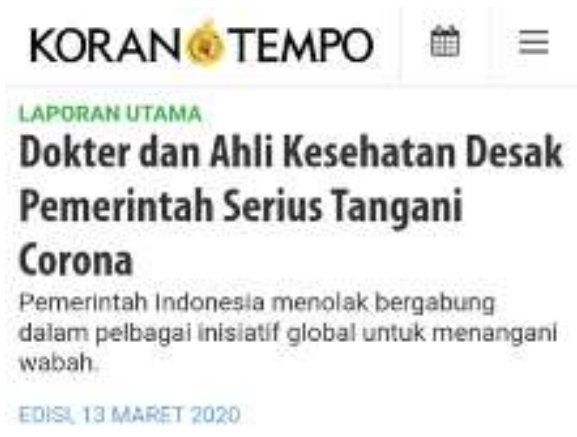

Figure 2. Headline of the $1^{\text {st }}$ news

The center of the headline in figure 2 is the clause "desak Pemerintah". Tempo's newspaper represent the government in this headline as the important parties in dealing with Covid-19, but the government seems underestimate this dangerous pandemic.

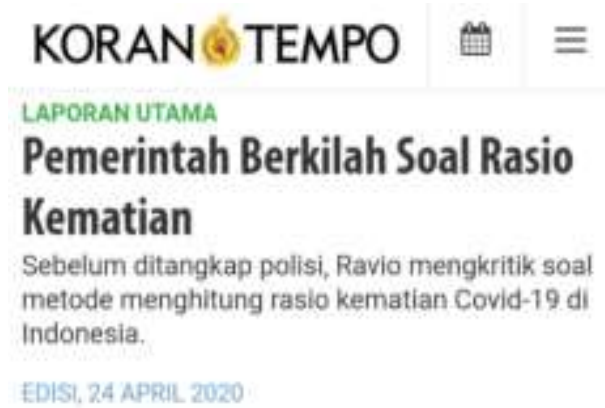

Figure 3. Headline of the 2nd news

The headline in figure 3 news shows "pemerintah berkilah". The clause indicate something is hidden behind the ratio of mortality. The arresting of Ravio who criticize the method of calculating Covid-19 death in Indonesia, strengthen the representation of the government by Tempo's newspaper.

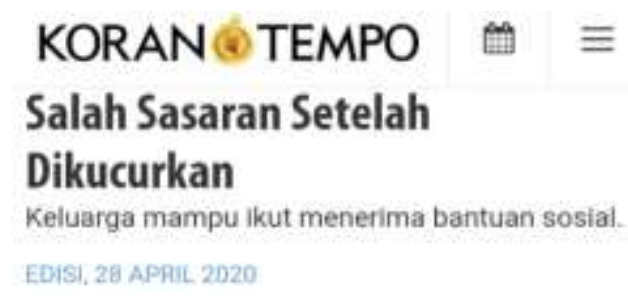

Figure 4. Headline of the 3rd news

The third headline of figure 4 "salah sasaran ketika dikucurkan, keluarga mampu ikut menerima bantuan sosial", indicates that the social assistance distribution from the government because of the government's policy, Pemabatasan Sosial Berskala Besar (PSBB), is not accordance with the reality in 
the field. Thus, the government's want to be seen working by the society by giving a social assistance without clarify the accurate data.

\section{KORAN TEMPO 曲 $\equiv$ Pemerintah Wajib Penuhi Kebutuhan Masyarakat \\ Banyak masyarakat yang tidak bisa memenuhi kebutuhan dasar setelah PSBB diberlakukan. \\ EDISL, 29 APAIL 2020}

Figure 5. Headline of the 4th news

The headline in figure 5 news, Tempo's newspaper is not reluctant for showing the citizen's need. The word "wajib" is chosen by Tempo in expressing the strong order that the government have to do.

\section{KORAN TEMPO $\Perp$ Mundurlah Terawan \\ Di tangan para tenaga kesehatan kini nasib \\ Indonesia bergantung. Menghadapi wabah corona, mereka berjbaku siang-malam.}

Figure 6. Headline of the 5th news

In the headline of the figure 6 news, Tempo write the clause "Mundurlah Terawan". There is an assessment based on the observations and interviews from several experts who stated that Terawan Agus Putranto's failure in facing Covid19 cases as the Minister of Health.

In the analysis of discourse, any discourse that arises is not neutral, but have a power and ideology (Francine Descarries, 2014). The intended concept of power is one of the relations between discourse and society. Based on the analysis of text dimension and discursive practice, the discourse in the form of news produced by Tempo's newspaper placed the informant who declare the government representation in dealing with Covid-19 in negative entity in the position of dominant group. In addition, in the news texts, Tempo's newspaper wrote in detail and at length the supporting informants descriptions. Whereas the protection statements from the government written in a small portion. Tempo's ideological representation provides a negative view of the government in dealing with Covid19 and not showing partiality towards the government.

Another function of the press in a democratic society has to do with the fact that democracy can work or become a fact of life political rights and civil liberties are needed to protect the interest minority groups from possible abuse of power. In this context, Tempo.co has a role as the press that has a function as the 'watchdog' serves to supervise those who have a power within politics (government) and nonprofit organizations.

In this connection, the press is considered the fourth power after the legislative, executive and judiciary, which is considered as one of the forces for guarantee checks and balances of the various powers that exist. In such a role as a press, Tempo.co try to be able to produce the investigative reports to highlight abuses of power which takes place in various existing institutions. Thus, the Tempo's newspaper will be able to provide an information that is different from 
information that may have been 'managed' by the government to protect their image. Currently, progress is in the fields of public relations and political marketing have been greatly exploited either by politicians or power holders to manage each event such that the government want to have a respectable image inside mass media. If such reports become the content of the mass media / press, political education is difficult to hope for indeed. Then attempt to deceive citizens through the manipulation of internal reports media.

In this case, Tempo.co assured the public that Tempo is an institution that avoided the citizen's assumption that production information and various events are carried out in a planned and creative manner manipulative relations between government and journalists also media executives. In critical discourse analysis, news production is reported by Tempo's newspaper be proof that discourse is not never been separated from the certain various interests of the parties that have an interest in it. Otherwise, in a discourse there must be 'something behind'. Media as an economic institution. Hence, the media is potential perform political maneuvers that are run through politics its news which is packaged as an information commodity trying to get around the demands and opportunities of the market. Thus, Tempo's newspaper led the readers to give a positive image to Tempo as an active and existent media in serving the truth. When the reader believes in the truth of the news reported by Tempo's newspaper and consume the Tempo's newspaper, then Tempo's newspaper will get a high profit.

\section{CONCLUSIONS}

In the dimension of discursive analysis, the relation between the content of media, especially the news is related to the media crew. Goenawan Mohamad is a chief commissioner in Tempo.co. He has no relation with the government staff. Tempo is the first institution that has no affiliation with the government. Tempo.co produce a media product that is free from all pressures by accommodating and distributing a fair share of different voices. Thus, Tempo's newspaper produced the news without any pressure from the government by reporting the public criticism against the government policies in dealing with Covid-19 cases.

In the dimension of sociocultural practice analysis, any discourse that arises is not neutral, but have a power and ideology. The press is considered the fourth power after the legislative, executive and judiciary, which is considered as one of the forces for guarantee checks and balances of the various powers that exist. In this context, Tempo.co portray this media as a 'watchdog' that serves to supervise those who have a power within politics (government). Tempo's newspaper produced text news that reflects to the government depiction in their policies. However, media as an economic institution. Thus, Tempo's newspaper led the readers to give a positive image to Tempo.co as an active and existent media in serving the truth. Tempo.co try to gain the public trust to consume their news, then Tempo will get a high profit in it.

\section{REFERENCES}

Altschull, J. (1995). Agents of Power: The Media and Public Policy. New York: Longman Publishers USA. 
Asghar, J. (2014). Words speak louder than actions: a critical analysis of ideological perspectives in media discourse, International Journal of Humanities and Social Sciences, 4 (5): 170-81.

Barker, C., Galasinki, D. (2001). Cultural Studies and Discourse Analysis: A dialogue on language and identity. London: SAGE Publications.

Bulan, A \& Kasman. (2018). Analisis wacana kritis pada pidato Ahok di Kepulauan Seribu. Transformatika: Jurnal Bahasa, Sastra, dan Pengajarannya. Vol. 2, No. 1, pp. 50-57, P-ISSN: 2549-5941, E-ISSN: 2549-6271. doi: 10.31002/transformatika.v2i1.555

Eriyanto. (2011). Analisis Wacana. Pengantar Analisis Teks Media. Yogyakarta : LKiS.

Fairclough, N. (1992). Discourse and Social Change. Cambridge: Polity Press.

Fairclough, N. (2003). Analysing Discourse: Textual analysis for social research. London: Routledge

Francine Descarries. 2014. Language Is Not Neutral: The Construction of Knowledge in the Social Sciences and Humanities. Signs: Journal of Women in Culture and Society, 39(3), 564-569. DOI: https://doi.org/10.1086/674347

Gee, J. P. (2005). An Introduction to Discourse Analysis: Theory and Method. London: Routledge.

Janks, H. (1997). 'Critical Discourse Analysis as a research tool', Discourse: Studies in the Cultural Politics of Education, 18(3), 329-342.

Lee, L.F., Hutton, A.,\& Shu, S. (2015).The Role of Social Media in the Capital Market: Evidence from Consumer Product Recalls. Journal of Accounting Research, Forthcoming. <https://ssrn.com/abstract=2557212>;

Purwanto, Y. (2017). Discursive strategies on ridwan kamil's status update: a critical discourse analysis. HUMANIORA, Vol. 8 No. 2 April 2017: 153164

Putra, H. P., Triyono, S. (2018). Critical discourse analysis on kompas.com news: gerakan \#2019gantipresiden. LEKSEMA Jurnal Bahasa dan Sastra, Vol.3 No. 2, E-ISSN: 2527-807X, P-ISSN: 2527-8088

Reah, D. (2005). The Language of Newspapers. Oxon: Routltedg.

Silalahi. (2010). Pemerintah Dan Media Massa Saling Membutuhkan. Pontianak : Bureau of Communication and Public Information. Retrived April 20, 2020, from: http://dephub.go.id/post/read/pemerintah-dan-media-massasaling-membutuhkan-2758

Sobur, A. (2009). Analisis Teks Media, Suatu Pengantar Untuk Analisis Wacana Analisis Semiotik, dan Analisis Framing. Bandung: PT Remaja Rosdakarya.

Suharyo, Surono, Mujid F. Amin. (2015). Representasi ideologi dan kekuasaan dalam bahasa: kajian teks media. HUMANIKA, Vol. 22 No. 2, ISSN 14129418 
Waller, Lloyd G. (2006). Introducing Fairclough's Critical Discourse Analysis Methodology for Analyzing Caribbean Social Problems: Going Beyond Systems, Resources, Social Action, Social Practices and Forces of Structure or Lack Thereof as Units of Analysis. The Journal of Diplomatic Language. 3/1. http://ssrn.com/abstract=912329

Westerman, D. (2013). A social network as information: The effect of system generated reports of connectedness on credibility on Twitter. Journal of Computers in Human Behavior 28 (2013) 199-206.

Zaini. (2015). The Discourse of Online Media Coverage on the Holly's Murder.

IPTEK-KOM, Vol. 17, 87-98.

\section{Data Resource:}

Dokter dan Ahli Kesehatan Desak Pemerintah Serius Tangani Corona. (2020). Retrieved from https://koran.tempo.co/read/laporan-utama/450960/dokterdan-ahli-kesehatan-desak-pemerintah-serius-tangani-corona?

Mundrulah Terawan. (2020). Retrieved from https://koran.tempo.co/read/editorial/451250/mundurlah-terawan?

Pemerintah Berkilah Soal Rasio Kematian. (2020). Retrieved from https://koran.tempo.co/read/laporan-utama/452142/pemerintah-berkilahsoal-rasio-kematian

Pemerintah Wajib Penuhi Kebutuhan Masyarakat. (2020). Retrieved from https://koran.tempo.co/read/metro/452266/pemerintah-wajib-penuhikebutuhan-masyarakat

Salah Sasaran Setelah Dikucurkan. (2020). Retrieved from https://koran.tempo.co/read/laporan-utama/452231/salah-sasaran-setelahdikucurkan

Tempo Media Group. (n.d.). Retrieved from https://korporat.tempo.co.id/tentang 